\title{
Evolution of body mass index in two historical series of adolescents
}

\author{
Isa de Pádua Cintra, ${ }^{1}$ Maria Aparecida Zanetti Passos, ${ }^{2}$ Mauro Fisberg, ${ }^{3}$ \\ Helymar Costa Machado4
}

\begin{abstract}
Objective: To verify the evolution of body mass index (BMI) between two studies of adolescent populations.

Methods: Data on the BMI of 8,020 adolescents aged 10 to 15 years living in the city of São Paulo, Brazil, and enrolled on the 2005 study entitled "The nutritional profile of adolescents at public and private schools in São Paulo" were compared with data from the 1989 National Nutrition and Health Census (PNSN - Pesquisa Nacional sobre Saúde e Nutrição). Binomial testing was used to compare proportions once both data sets had been transformed into percentiles.
\end{abstract}

Results: Comparing the two surveys, significant increases were identified in 85th and 95th percentile BMI values for male adolescents aged 10 to 15 years and for female adolescents aged 10 to 14 years. Analysis of the difference between the 5th and 95th BMI percentiles of the São Paulo and PNSN samples indicates that there was probably an increase in the number of adolescents in the higher BMI ranges in São Paulo in relation to the PNSN survey.

Conclusions: These results demonstrate a tendency for the adolescents' observed mean BMI values to increase during the period between the two surveys, indicating a need for increased monitoring of this measurement as a form of preventing overweight in this population.

J Pediatr (Rio J). 2007;83(2):157-162: Adolescents, body mass index, overweight, obesity.

\section{Introduction}

Obesity in children and adolescents has been increasing rapidly in many cities in Brazil and in other countries, indicating that this is no longer just a public health problem for western countries. ${ }^{1}$ This being so, the World Health Organization $^{2}$ (WHO) has recognized obesity as a major public health epidemic worldwide, indicating a need for practical and viable investigative methods that estimate its prevalence and allow for international comparisons. ${ }^{3}$
In Brazil, a process of nutritional transition took place between 1974/1975 and 1989, with reductions in infant malnutrition and increases in obesity, ${ }^{4}$ from which it was projected that there would be an annual increase of $0.5 \%$ in the number of obese children. ${ }^{5}$ In fact, overweight and obesity already affect $20 \%$ of children and adolescents in Brazilian cities, with an observed prevalence in Recife of $35 \%,{ }^{6}$ and $15.8 \%$ in Salvador. ${ }^{7}$ In the city of Santos, state of São Paulo, $15.7 \%$ of overweight and $18 \%$ of obesity were observed. ${ }^{8,9}$ While many of these studies may not be

1. Nutricionista. Professora adjunta, Centro de Atendimento e Apoio ao Adolescente, Departamento de Pediatria, Universidade Federal de São Paulo - Escola Paulista de Medicina (UNIFESP-EPM), São Paulo, SP, Brasil.

2. Nutricionista. Mestre, Programa de Pós-Graduação Especialidades Pediátricas, Departamento de Pediatria, UNIFESP-EPM, São Paulo, SP, Brasil.

3. Médico. Professor adjunto, Centro de Atendimento e Apoio ao Adolescente, Departamento de Pediatria, UNIFESP-EPM, São Paulo, SP, Brasil.

4. Estatístico, Departamento de Estatística, Universidade Estadual de Campinas (UNICAMP), Campinas, SP, Brasil.

Manuscript received Jul 10 2006, accepted for publication Nov 012006.

Suggested citation: Cintra IP, Passos MA, Fisberg M, Machado HC. Evolution of body mass index in two historical series of adolescents. J Pediatr (Rio J). 2007;83(2):157-162.

doi 10.2223/JPED. 1602 
representative of their regions, the study in Santos ${ }^{8,9}$ stands out as it was populational and not sampled.

Obesity is associated with important health problems in the pediatric population. Body mass index $(\mathrm{BMI})^{10-12}$ is an early risk factor for morbidity and mortality, in addition to being a measurement widely correlated with these conditions, both in children and the adult population. Many studies have used BMI values between the 85th and 95th percentiles, by age and sex, to classify overweight, and values equal to or greater than the 95th percentile to classify obesity. ${ }^{12-14}$ It is important to point out that overweight is defined as excess total body weight, based on a specific weight cutoff, whereas obesity is excess total or localized body fat. ${ }^{3}$

The objective of this study is to compare the distribution of BMI percentiles among adolescents aged 10 to 15 years recently evaluated in the city of São Paulo with data from the Brazilian Institute of National Statistics and Geography and the National Institute of Food and Nutrition, based on results from the National Nutrition and Health Census (PNSN Pesquisa Nacional sobre Saúde e Nutrição) ${ }^{15}$ and published by Anjos et al., ${ }^{16}$ as a means of monitoring the evolution of overweight and obesity within this population from São Paulo.

\section{Methods}

The study enrolled 8,020 adolescents, $55 \%(4,372)$ of whom were female and $46 \%(3,648)$ of whom were male, students at 43 schools ( 32 public and 11 private ones) in the North (17\%), Midwest (17\%), East (37\%) and South (29\%) zones of São Paulo city.

Information on the number of schools in São Paulo was provided by the Delegacias Regionais de Ensino (local educational directorates), which were chosen at random, with the exception of any with less than 200 students enrolled in the 5 th to 8 th grades. Schools that objected to participation were replaced with others, also selected at random, with the proportion of public and private schools maintained.

Schools participated after authorization from their boards, and adolescents only participated if they provided written consent from their parents or guardians. Exclusion criteria for adolescents were: pregnancy, age less than 10 years or more than 15 years and any physical condition that precluded routine anthropometric assessment.

This study is part of the Adolescent Obesity Early Diagnosis and Lifestyle Project which aims to delineate the nutritional profile of students at public and private schools. The project was coordinated by the Adolescent Care and Support Center (CAAA - Centro de Atendimento e Apoio ao Adolescente) at the UNIFESP Pediatrics Department and by the Physical Activity and Weight Control Task Force (Força Tarefa de Atividade Física e Controle de Peso - ILSI Brazil).

This study conforms to ethical principals for research involving human beings, in accordance with resolution CNS 196/96, and was approved by the Research Ethics Committee at the Universidade Federal de São Paulo (CEP no 0977/03).

Anthropometric assessment was performed by a team of 20 interns and five coordinators, trained in advance in the techniques and standardization of the methods employed.

Subjects were weighed using a Seca ${ }^{\circledR}$ portable digital scale with a $150 \mathrm{~kg}$ capacity, standing on the base plate, unshod, wearing light clothing and with their arms aligned with their bodies. Height was measured using a Seca ${ }^{\circledR}$ wall stadiometer at $90^{\circ}$ to the floor, in accordance with parameters defined by Jelliffe ${ }^{17}$ and the WHO. ${ }^{18}$ These measurements were used to calculate BMI, by dividing weight in $\mathrm{kg}$ by the square of stature in $\mathrm{m}$, and nutritional status was assessed according to the criteria proposed by the Centers for Disease Control and Prevention. ${ }^{19}$

In order to describe the profile of the sample, according to the various study variables, frequency tables were constructed for categorical variables and descriptive statistics (mean, standard deviation, minimum and maximum values) were used for continuous variables (age, height, weight and BMI).

The BMI data were put in order from the least value (minimum) to the greatest (maximum) and subdivided into 100 equal sized parts, known as percentiles, adopting the values at P5, P15, P25, P50, P75, P85 and P95, by sex and age group.

In order that the BMI percentiles for the two studies could be compared, the figures obtained in the National Nutrition and Health Census were fixed and compared to those from the São Paulo sample. Analysis was by age and sex, using binomial testing to compare proportions between the studies.

\section{Results}

The female $(n=4,372)$ and male $(n=3,648)$ adolescents exhibited very similar mean values for age (13.03 and 13.06 years), weight (49.48 and $50.55 \mathrm{~kg}$ ), height (155.77 and $157.75 \mathrm{~cm}$ ) and BMI (20.26 and $\left.20.07 \mathrm{kgm}^{2}\right)$.

The distribution of BMI across percentiles of 10 to 15 year-old female and male adolescents from the city of São Paulo are presented in Table 1, and the equivalent data for adolescents from the same age group, as published by Anjos et al., ${ }^{16}$ according to the PNSN data (1989) are in Table 2.

Comparative analyses will now be presented of the BMI percentiles for the adolescents from São Paulo city ( $n=8,020)$ and the 1989 PNSN values $(n=8,701)$, broken 
down by age and sex. Taking the P85 and P95 values from the PNSN as fixed points, the corresponding percentage of adolescents in the São Paulo sample whose BMI was within those limits was calculated. The binomial test was then used to compare proportions in order to detect significant differences between the values expected for P85 and P95.
Table 3 shows that there were significant differences in the values at P85 and P95 for all age and sex combinations, with the exception of P85 for 15-year-old females.

The results shown in Table 4 demonstrate that there was a significant difference between the samples in the values for

Table 1 - Distribution of adolescents in the city of São Paulo by age and sex (2005) according to body mass index percentile

\begin{tabular}{|c|c|c|c|c|c|c|c|}
\hline Sex/Age (years) & P5 & P15 & P25 & P50 & P75 & P85 & P95 \\
\hline \multicolumn{8}{|l|}{ Female } \\
\hline $10(n=180)$ & 14.69 & 15.61 & 16.42 & 18.18 & 20.80 & 22.17 & 25.41 \\
\hline $11(n=891)$ & 15.09 & 15.99 & 16.78 & 18.69 & 21.15 & 22.66 & 25.84 \\
\hline $12(n=999)$ & 15.16 & 16.43 & 17.27 & 19.22 & 21.56 & 23.39 & 26.89 \\
\hline $13(n=1,106)$ & 16.28 & 17.34 & 18.15 & 20.00 & 22.24 & 23.95 & 27.49 \\
\hline $14(n=962)$ & 16.61 & 17.89 & 18.83 & 20.81 & 22.95 & 24.59 & 27.63 \\
\hline $15(n=234)$ & 17.40 & 18.53 & 19.31 & 20.65 & 22.50 & 24.11 & 27.79 \\
\hline \multicolumn{8}{|l|}{ Male } \\
\hline $10(n=134)$ & 15.16 & 15.92 & 16.48 & 17.77 & 20.63 & 22.55 & 25.93 \\
\hline $11(n=765)$ & 15.22 & 16.01 & 16.70 & 18.49 & 21.45 & 23.24 & 26.15 \\
\hline $12(n=816)$ & 15.06 & 16.18 & 16.88 & 18.71 & 21.64 & 23.64 & 27.02 \\
\hline $13(n=904)$ & 15.55 & 16.89 & 17.70 & 19.50 & 22.31 & 24.26 & 28.30 \\
\hline $14(n=787)$ & 16.44 & 17.57 & 18.27 & 19.71 & 22.22 & 23.86 & 27.70 \\
\hline $15(n=242)$ & 16.61 & 17.67 & 18.65 & 20.36 & 22.47 & 24.00 & 29.84 \\
\hline
\end{tabular}

Table 2 - Distribution of adolescents by age and sex according to body mass index percentile, 1989 National Nutrition and Health Census

\begin{tabular}{cccccccc}
\hline Sex/Age (years) & P5 & P15 & P25 & P50 & P75 & P85 & P95 \\
\hline Female & & & & & & & \\
$10(n=776)$ & 13.50 & 14.60 & 15.10 & 16.30 & 17.60 & 18.60 & 21.00 \\
$11(n=768)$ & 14.10 & 15.10 & 15.60 & 16.80 & 18.60 & 19.80 & 22.80 \\
$12(n=757)$ & 14.70 & 15.70 & 16.40 & 17.90 & 19.60 & 20.90 & 23.40 \\
$13(n=713)$ & 15.40 & 16.70 & 17.40 & 19.00 & 21.10 & 22.20 & 24.30 \\
$14(n=699)$ & 16.10 & 17.30 & 18.30 & 20.00 & 21.90 & 23.30 & 26.00 \\
$15(n=615)$ & 17.10 & 18.30 & 19.00 & 20.60 & 22.50 & 23.60 & 26.00 \\
Male & & & & & & & \\
$10(n=780)$ & 14.10 & 14.80 & 15.20 & 16.10 & 17.10 & 18.00 & 20.00 \\
$11(n=782)$ & 14.30 & 15.10 & 15.60 & 16.50 & 17.60 & 18.70 & 21.30 \\
$12(n=721)$ & 14.50 & 15.40 & 15.90 & 16.90 & 18.20 & 19.10 & 22.00 \\
$13(n=732)$ & 15.10 & 16.00 & 16.50 & 17.70 & 19.20 & 20.10 & 21.90 \\
$14(n=742)$ & 15.40 & 16.40 & 17.10 & 18.30 & 19.80 & 20.80 & 22.40 \\
$15(n=616)$ & 15.70 & 17.20 & 17.80 & 19.10 & 20.70 & 21.70 & 23.80 \\
& & & & & & & \\
\hline
\end{tabular}


Table 3 - Comparative analysis of the 85th and 95th percentiles for body mass index for the São Paulo and National Nutrition and Health Census (PNSN) samples

\begin{tabular}{|c|c|c|c|c|c|c|}
\hline Sex/Age (years) & $\begin{array}{c}\text { BMI value at } \\
\text { P85 in the PNSN }\end{array}$ & $\begin{array}{l}\text { Percentile in } \\
\text { São Paulo* }\end{array}$ & $\mathbf{p}^{+}$ & $\begin{array}{c}\text { BMI value at } \\
\text { P95 in the PNSN }\end{array}$ & $\begin{array}{c}\text { Percentile } \\
\text { in São Paulo }\end{array}$ & $p^{\S}$ \\
\hline \multicolumn{7}{|l|}{ Female } \\
\hline 10 & 18.6 & P59 & $p<0.001$ & 21.0 & P77 & $p<0.001$ \\
\hline 11 & 19.8 & P64 & $p<0.001$ & 22.8 & P86 & $p<0.001$ \\
\hline 12 & 20.9 & P70 & $p<0.001$ & 23.4 & P85 & $p<0.001$ \\
\hline 13 & 22.2 & P75 & $p<0.001$ & 24.3 & P87 & $p<0.001$ \\
\hline 14 & 23.3 & P78 & $p<0.001$ & 26.0 & P91 & $\mathrm{p}<0.001$ \\
\hline 15 & 23.6 & P82 & $p=0.207$ & 26.0 & P91 & $p=0.013$ \\
\hline \multicolumn{7}{|l|}{ Male } \\
\hline 10 & 18.0 & P51 & $p<0.001$ & 20.0 & P69 & $p<0.001$ \\
\hline 11 & 18.7 & P51 & $p<0.001$ & 21.3 & P73 & $p<0.001$ \\
\hline 12 & 19.1 & P54 & $p<0.001$ & 22.0 & P77 & $\mathrm{p}<0.001$ \\
\hline 13 & 20.1 & P59 & $p<0.001$ & 21.9 & P73 & $p<0.001$ \\
\hline 14 & 20.8 & P63 & $p<0.001$ & 22.4 & P76 & $p<0.001$ \\
\hline 15 & 21.7 & P65 & $p<0.001$ & 23.8 & P84 & $p<0.001$ \\
\hline
\end{tabular}

* Percentile or percentage of adolescents in the São Paulo sample whose BMI is below P85 for the PNSN sample, by age and sex. ${ }^{+} \mathrm{p}$ value from the binomial test when the value from the São Paulo population is compared with P85 of the PNSN sample.

* Percentile or percentage of adolescents in the São Paulo sample whose BMI is below P95 for the PNSN sample, by age and sex.

$\S \mathrm{p}$ value from the binomial test when the value from the São Paulo population is compared with P95 of the PNSN sample.

Table 4 - Comparative analysis of the P5 to P95 range of body mass index from the National Nutrition and Health Census (PNSN) with the sample

\begin{tabular}{|c|c|c|c|c|}
\hline Sex/Age (years) & $\begin{array}{l}\text { BMI value at P5 } \\
\text { in the PNSN }\end{array}$ & $\begin{array}{l}\text { BMI value at P95 } \\
\text { in the PNSN }\end{array}$ & $\begin{array}{l}\text { Percentage for } \\
\text { São Paulo* }\end{array}$ & $\mathbf{p}^{+}$ \\
\hline \multicolumn{5}{|l|}{ Female } \\
\hline 10 & 13.8 & 21.0 & 75.0 & $p<0.001$ \\
\hline 11 & 14.1 & 22.8 & 84.5 & $p<0.001$ \\
\hline 12 & 14.7 & 23.4 & 82.4 & $p<0.001$ \\
\hline 13 & 15.4 & 24.3 & 85.3 & $p<0.001$ \\
\hline 14 & 16.1 & 26.0 & 87.6 & $p=0.014$ \\
\hline 15 & 17.1 & 26.0 & 87.6 & $p=0.222$ \\
\hline \multicolumn{5}{|l|}{ Male } \\
\hline 10 & 14.1 & 20.0 & 68.7 & $p<0.001$ \\
\hline 11 & 14.3 & 21.3 & 71.9 & $p<0.001$ \\
\hline 12 & 14.5 & 22.0 & 75.4 & $p<0.001$ \\
\hline 13 & 15.1 & 21.9 & 70.1 & $p<0.001$ \\
\hline 14 & 15.4 & 22.4 & 74.8 & $p<0.001$ \\
\hline 15 & 15.7 & 23.8 & 82.6 & $p<0.001$ \\
\hline
\end{tabular}

* Percentage of adolescents from the São Paulo sample whose BMI falls within P5 to P95 in the PNSN sample, by age and sex.

+ $\mathrm{p}$ value when binomial testing is used to compare the actual percentage in the São Paulo population with the expected percentage of $90 \%$ (P95-P5 from the PNSN). 
the difference between P5 and P95, for each age and sex combination with the exception of 15 -year-old females. In each case the percentage of adolescents from the 2005 sample falling within this range is lower than the expected $90 \%$, indicating a probable increase in the number of adolescents in the upper BMI bands.

\section{Discussion}

Anthropometric measurements are widely used for evaluation of the nutritional status of individuals and populations, since they are more practical and of lower cost, but, in common with any assessment method, they have their limitations. ${ }^{20-22}$

This study has demonstrated that the adolescents of São Paulo, from 10 to 15 years of age, are exhibiting a significant increase in BMI at the different percentiles, indicating that, as the years pass, there is an ever increasing tendency towards gaining body weight, particularly among males.

A study comparing national surveys from 1975 and 1997 observed that, among girls, there was an increase of around 5 units of BMI at the 95th percentile for ages 10 to 12 years and of around 3 units for those aged 13 years or more, with the greatest increases occurring at the upper limits of the distribution. ${ }^{22}$ Over a shorter period we also identified significant increases among females, and the greatest increases also occurred among the younger girls and at the upper limits of BMI.

Another study compared data on British adolescents aged 11 to 16 years from the National Diet and Nutrition Survey with figures from the British Standards Institute, ${ }^{23}$ using standard deviation scores, and found a mean increase in BMI of 0.47 and 0.53 units, for males and females respectively. Although our study did not use scores to analyze BMI, it will be noted that while the British study observed the greatest increases among females, here the opposite was true. One important point is that our study assessed males and females simultaneously, which was not the case with the British Standards Institute data, and so there was no temporal interference, which we now know has a significant impact, not only on the increasing prevalence of obesity, but also on its severity.

Data from the PNSN were used to calculate recently published cutoff points for the assessment of nutritional status in Brazilian children and adolescents, and the BMI values used for overweight and obesity ${ }^{24}$ were lower than those at the 85th and 95th percentiles for the 10 to 15 -year-old adolescents from São Paulo. These data reaffirm the tendency for body weight to increase in this population.

Passos $^{25}$ compared BMI data for adolescents from São Paulo city at varying percentiles with data published by Must et al. ${ }^{26}$ the $\mathrm{CDC}^{27}$ and Cole et al., ${ }^{19}$ and also found that these adolescents exhibited cutoff points that were higher than the international parameters, being closer to the cutoff points established by Cole, demonstrating that the values observed in this population are well above those considered appropriate. The principal differences occurred at the upper extremities (P85 and P95) and among the younger adolescents of both sexes.

With the objective of arresting this increase in the prevalence of obesity among young Brazilians, ${ }^{14,28,29}$ we suggest that the more rigid evaluation criteria be adopted, such as the cutoff points recently proposed for the Brazilian population, ${ }^{24}$ which, in addition to being defended by international authors, ${ }^{3}$ are a closer approximation to the reality in our country, allowing for overweight to be diagnosed earlier, so that interventions aimed at impacting juvenile obesity can be established, as a means of achieving better quality of life. ${ }^{1,3,24,25,30}$

\section{References}

1. Stettler N. Comment: the global epidemic of childhood obesity: is there a role for the paediatrician? Obes Rev. 2004;5 Suppl $1: 1-3$.

2. World Health Organization. Obesity: preventing and managing the global epidemic. Report of the WHO Consultation on Obesity. Geneva: WHO; 1998.

3. Tomkis A. Measuring obesity in children: what standards to use? J Pediatr (Rio J). 2006;82:246-8.

4. Monteiro CA, Mondini L, Medeiros SAL, Popkin BM. The nutrition transition in Brasil. Eur J Clin Nutr. 1995;49:105-13.

5. Lobstein T, Baur L, Uauy R; IASO International Obesity TaskForce. Obesity in children and young people: a crisis in public health. Obes Rev. 2004;5 Suppl 1:4-104.

6. Balaban G, Silva GAP. Prevalência de sobrepeso e obesidade em crianças e adolescentes de uma escola da rede privada de Recife. J Pediatr (Rio J). 2001;77:96-100.

7. Souza Leão SC, Araújo LMB, Moraes LTLP, Assis AM. Prevalência de obesidade em escolares de Salvador, Bahia. Arq Bras Edocrinol Metab. 2003;47:151-7.

8. Costa RF, Cintra IP, Fisberg M. Prevalência de sobrepeso e obesidade em escolares da cidade de Santos, SP. Arq Bras Endocrinol Metab. 2006;50:60-7.

9. Costa RF, Fisberg M, Soderberg TR, Maxta JB, Cunha JSN, Soderberg ARF, et al. Prevalência do sobrepeso e obesidade em crianças de 7 a 10 anos de escolas públicas e particulares da cidade de Santos-SP. Arq Bras Endocrinol Metab. 2003;47:S371.

10. Pereira CVR, Silva CS, Anjos LA. Tendência na disponibilidade de energia e macronutrientes para a população brasileira nos últimos 40 anos. Anais do $12^{\circ}$ Seminário de Iniciação Científica. Niterói: Universidade Federal Fluminense; 2002.

11. Burlandy L, Anjos LA. Acesso a vale-refeição e estado nutricional de adultos beneficiários do Programa de Alimentação do Trabalhador no Nordeste e Sudeste do Brasil, 1997. Cad Saude Publica. 2001;17:1457-64.

12. Bellizzi MC, Dietz WH. Workshop on childhood obesity: summary of the discussion. Am J Clin Nutr. 1999;70:173S-5S. 
13. Wang $Y$, Wang JQ. A comparison of international references for the assessment of child and adolescent overweight and obesity in different populations. Eur J Clin Nutr. 2002;56:973-82.

14. Wang Y, Monteiro CA, Popkin BM. Trends of obesity and underweight in older children and adolescents in the United States, Brasil, China, and Rússia. Am J Clin Nutr. 2002;75:971-7.

15. Instituto Brasileiro de Geografia e Estatística, Fundo das Nações Unidas para a Infância (IBGE/UNICEF). Perfil estatístico de crianças e mães no Brasil: aspectos de saúde e nutrição de crianças no Brasil. Rio de Janeiro: IBGE; 1992.

16. Anjos LA, Veiga GV, Castro IRR. Distribuição dos valores do índice de massa corporal da população brasileira até 25 anos. Rev Panam Salud Publica. 1998;3:164-73.

17. Jellife DB. Evaluación del estado de nutrición de la comunidad. Ginebra: OMS; 1968.

18. World Health Organization (WHO). Expert Committee on Physical Status: the use and interpretation of anthropometry. Vol. 854. Geneva: WHO; 1995.

19. Cole TJ, Bellizzi MC, Flegal KM, Dietz WH. Establishing a standard definition for child overweight and obesity worldwide: international survey. BMJ. 2000;320:1240-3.

20. Organización Mundial de La Salud (OMS). La salude de los jovens: desafio para la sociedad. Informe de un grupo de estúdios de la OMS acerca de los jovens y la salud para todos en el año 2000. Ginebra: OMS; 1999.

21. Veiga GV, Vieira ACR, Alvarez MM, Pereira RC. Body mass index in assessment of overweight and obesity in children and adolescents: agreement and disagreement. Nutrire Rev Soc Bras Aliment Nutr. 2004;28:109-24.

22. Veiga GV, Cunha AS, Sichieri R. Trends in overweight among adolescents living in the poorest and richest regions of Brazil. Am J Public Health. 2004;94:1544-8.
23. McCarthy HD, Ellis SM, Cole TJ. Central overweight and obesity in British youth ages 11-16 years: cross sectional surveys of waist circumference. BMJ. 2003;326:624.

24. Conde WL, Monteiro CA. Body mass index cutoff points for evaluation of nutritional status in Brazilian children and adolescents. J Pediatr (Rio J). 2006;82:266-72.

25. Passos MAZ. Percentis, por idade e sexo, do índice de massa corporal e das circunferências do braço, da cintura, do quadril e da relação cintura/quadril, de adolescentes de 10 a 15 anos da cidade de São Paulo [tese]. São Paulo: Universidade Federal de São Paulo; 2005.

26. Must A, Dallal GE, Dietz WH. Reference data for obesity: 85th and 95th percentiles of body mass index (wt/ht2) and triceps skinfold thickness. Am J Clin Nut. 1991;53:839-46.

27. CDC 2000. Growth charts for the United States: methods and development. Series report 11, no 246.201. Atlanta: CDC; 2000.

28. Mendonça CP, Anjos LA. Aspectos das práticas alimentares e da atividade física como determinantes do crescimento do sobrepeso/obesidade no Brasil. Cad Saude Publica. 2004;20:698-709.

29. Instituto Brasileiro de Geografia e Estatística. Pesquisa de orçamentos familiares: medidas antropométricas de crianças e adolescentes 2002-2003. Rio de Janeiro: IBGE; 2004.

30. Katzmarzyk PT, Janssen I, Ross R, Church TS, Blair SN. The importance of waist circumference in the definition of metabolic syndrome: prospective analyses of mortality in men. Diabetes Care. 2006;29:404-9.

Correspondence:

Isa de Pádua Cintra

Rua Botucatu, 715

CEP 04023-062 - São Paulo, SP - Brazil

Tel.: +55 (11) 5576.4360, +55 (11) 5579.7387

E-mail: ipcintra@uol.com.br; cidazpassos94@yahoo.com.br 